\title{
Determining destination risk perceptions, their effects on satisfaction, revisit and recommendation intentions: Evidence from Sanliurfa/Turkey
}

\author{
Ali Rıza Mancı
}

Keywords:

Destination,

Recommendation intention, Revisit intention,

Risk perception,

Satisfaction,

Sanliurfa

Tourists

\section{Article History:}

Submitted: 29.08.2021

Revised: 27.11 .2021

Revised: 10.01 .2022

Accepted: 25.01.2022

Published Online: 26.01.2022

\begin{abstract}
Visitors' risk perception plays a vital role in their destination choice, intention to return, satisfaction and recommendations to others. At the same time, perceived risks affect destination image, which in turn causes increased or decreased demand for attractions of destinations. The aim of this study is to determine risk dimensions and their effects on recommendation and revisit intentions. Scale is most widely used in tourism research. This scale consists of six dimensions, namely, physical, time, social, performance, financial, and psychological risks, which consist of 28 items. A total of 471 respondents were collected via convenience sampling method among domestic tourists who visited Sanliurfa from May to June 2021. The results of the study indicated a weak inverse and significant relationship between the performance, social, physical, psychological, financial, and time risk perception of the participants and general satisfaction levels. Meanwhile, there is a moderately strong, inverse and significant relationship between all dimensions of risk perception among the participants and their recommendation and revisit intention. Thus, perceptions of risk dimensions have a strong negative influence on overall satisfaction, recommendation, and revisit intentions. By employing three regression models, the present study reported that time and psychological risks highly affect all dependent variables. Furthermore, overall satisfaction is significantly affected by the physical and performance dimensions. Recommendation intention is affected by the financial dimension beyond the aforementioned dimensions. The overall satisfaction levels of the participants were highly correlated with their recommendation levels and revisit intention. At the same time, their recommendation intention was highly correlated with their level of revisit intention. It might be said that visitors may change their future behaviors according to travel risk perceptions. Finally, the study revealed that understanding of customers risk perception is essential to all tourism and hospitality stakeholders.
\end{abstract}

\section{Introduction}

Customer perceptions of processes and prospective outcomes influence their purchasing decisions (Pelaez, Chen, \& Chen, 2019). As a result, understanding customer behavior is critical for a destination's present services to succeed and aids in the discovery of strategies to increase customer loyalty (Cong, 2021), leading to increased revenue and a powerful brand, which in turn improve customer retention (Eid, 2015). Satisfied customers share their happy experiences with their relatives. In other words, they are willing to repurchase and make recommendations to others. This can be observed in the review studies of Hasan, Ismail, and Islam (2017) and Lu (2021) and research by Cetinsoz and Ege (2013). They stated that some risk dimensions affect repeat behavior. Their findings support prior research that found a link between perceived risks and desire to return (An, Lee, \& Noh, 2010).

Perceived risk has attracted the attention of many academics and has been acknowledged as a basic topic in customer behavior, with a large body of knowledge exploring its implications on customer decisions (Bettman, 1973; Sharifpour, Walters, Ritchie, \& Winter, 2014). Particularly in tourism research, perceived risks connected with a destination have been proven to generate a significant impact on visitors' decisions to visit or reject a destination (Fuchs \& Reichel, 2006; Karl, Muskat, \& Ritchie, 2020).

Psychological (Kovačić et al., 2019), economic (Tiwari, Das, \& Dutta, 2019), social (Emami \&

Ali Rıza Mancı: Asist. Prof., Harran University, Sanliurfa, Turkey, Email: armanci@ harran.edu.tr, Orcid Id: 0000-0003-4618-5891 (iD 
Ranjbarian, 2019), personal (Osland, Mackoy, \& McCormick, 2017), cultural (Reisinger \& Mavondo, 2006), and demographic factors (Yazid et al., 2018) are currently known regarding traveler-perceived risk dimensions through existing literature. In addition, some concepts including risk, values, motivations, expectations, attitudes, perceptions, satisfaction, trust, and loyalty are crucial and can modify the decision-making of tourist behavior in tourism contexts (Cohen, Prayag, \& Moital, 2014). Scholars have investigated their effects on tourists' destination choices (Hasan et al., 2017).

Risk is an important cognitive stimulus that scholars have been discussing in customer destination decision processes in tourism so far. In turn, the definition of risk perception is under debate (Wolff, Larsen, \& Øgaard, 2019). Many scholars have defined risk differently because the impact of risk on tourists' decision-making processes varies from person to person, as "there are different levels of acceptable risk within the socio-psychological range of tourists" (Caber, González-Rodríguez, Albayrak, \& Simonetti, 2020). The indefiniteness of the concept has been noted by many researchers (Le \& Arcodia, 2018; Larsen, Doran, \& Wolff, 2017; Reisinger \& Mavondo, 2006; Yang \& Nair, 2014). A common point of the definitions is the possibility or likelihood of loss when events occur. In other words, risk can be predicted and calculated by sides, but uncertainty cannot. It has unpredictable characteristics.

Absolute or real and subjective perceptions can be considered as two types of risks in the research agenda. While the probability of unfavorable outcomes with a real risk is weighted by severity (Wolff et al., 2019) such as tsunamis, earthquakes, and other natural disasters, subjective risk is manmade and directly related to travelers, destinations, and business perceptions (Ritchie \& Jiang, 2019). Thus, one of the effective factors of customer purchase behavior is their perception of what they prefer to purchase.

In the service industry, the importance of subjective risk as a fundamental determinant of customer behavior has been widely documented (Casidy \& Wymer, 2016). For instance, Kozak, Crotts, \& Law, (2007) revealed that international visitors predominantly expect to change their plans according to their perception of risk in a destination.

Determining the risk perceptions of visitors has become more important given that higher risk perception causes lower travel desire or intention
(Floyd \& Pennington-Gray, 2004). Moreover, (Sönmez \& Graefe, 1998) pointed out that risk perceptions are significant in the decision-making of international visitors, reflecting views such as travel is hazardous and travelers are likely to become victims of terrorist attacks. The effects of terrorist attacks against tourists on tourism is also investigated by (Güvenek \& Alptekin, 2015). They pointed out that terrorist attacks against visitors have a detrimental impact on the country's tourism. Parallel findings were maintained by many scholars (Baumert, de Obesso, \& Valbuena, 2020; Mawby, Ozascilar, \& Ziyalar, 2021). A similar effect has been observed in the Covid-19 pandemic encountered in recent years. For example, it is possible to say that the Covid-19 pandemic might have a significant impact on travelers' perceptions of hygiene and safety (Cetinkaya, Ozer, \& Altuner, 2020). Additionally, Wen, Kozak, Yang, \& Liu, (2021) indicated that Covid-19 altered the behaviors of tourists when they travel and the fear of Covid-19. Resulting people prefer to travel with small groups and become more "responsible tourists" (Rahmafitria, Suryadi, Oktadiana, Putro, \& Rosyidie, 2021). Moreover, Dedeoğlu \& Boğan (2021) pointed out that the association between some motivating elements and visit intention is moderated by consumers' Covid-19 risk perception and their trust in government.

Tourism risk also affects a destination's image (Ruan, Li, \& Liu, 2017). Consequently, to attract more tourists, destinations must have a positive image and a low perceived risk level (Savascı, 2020). Tourist perceptions before, during, and after visits are influenced by image and risk, which shape tourists' behavioral intentions. In addition, intention to revisit and recommendation to others are affected precisely by the destination risk perception of visitors (Cui, Liu, Chang, Duan, \& Li, 2016).

Customers' postponement, corrections, or cancellations of buying decisions are strongly affected by their risk perceptions, which are major factors in altering purchasing behavior and determining costumers' experiences and level of satisfaction. As a result, destination managers must be knowledgeable about terms that influence visitors' purchasing decisions (Gong \& Liang, 2019). Destination risk perceptions may directly influence tourists' destination choices. Thus, it is crucial to evaluate the risk perception of tourists' visiting destinations. 
Despite the growing amount of published research about travelers' risk perception, empirical studies are limited. Furthermore, there is no study on the risk perception of domestic visitors to Sanliurfa, Turkey, particularly. Because, it is critical to understand how visitors' perceptions of risk impact their willingness to travel to a destination (Hashim, Noor, Awang, Che Aziz, \& Yusoff, 2018). To fill this knowledge gap, the aims of the study are (1) to evaluate dimensions of risks (performance, physical, time, psychological, financial and social) (2) to examine their effects on recommendations and revisit intentions. Thus, readers can expect to find relationship between risk dimensions, and revisit and recommendation intention. Thus, for it is important to understand customers risk perceptions to implement "strategies to be taken by the tourism and hospitality managers" (Koc \& Villi, 2021).

\section{Literature Review}

\section{Definition of risk and its dimensions}

Since risk is an important concept in tourism research, there is a growing research interest in the risk perceptions of visitors. Apparently, risk and tourism are closely related to each other. Risk is broadly defined as the probability of negative outcomes of preference, and a hazard or dangerous chance was defined as the exposure to the possibility of injury or loss (Reisinger \& Mavondo, 2005). In other words "it is not real, as it has not happened yet; risk is a possible future condition" (Clayton, Mustelier, \& Korstanje, 2014).

Risk has an essential role in influencing visitor behavior, particularly in the context of travel and tourism, because tourism is an intangible service that is vulnerable to possible hazards and dangers (Hashim, et al., 2018). According to previous research, uncertainty, worry, fear, and anxiety are all intertwined and proven to be closely connected to risk perception. In previous research, these concepts were used interchangeably, causing difficulty in interpreting visitors' experiences (Yang \& Nair, 2014). Risk (perception) as a concept is an interdisciplinary phenomenon that has been studied by many researchers from various sciences such as physiology, sociology, economics, culture, management, particularly tourism destination management, etc. Some researchers pointed out that it is a comprehensive term which includes uncertainty and negative outcomes (Hashim, et al., 2018).

First, although Jacoby and Kaplan (1972) introduced six risk perception dimensions, which are physical, time, performance, financial, social, and psychological risks (Hasan et al., 2017), some scholars added such dimensions as political instability, safety, terrorism (Supani \& Abd Hamid, 2020), and destination risk (Perić, Dramićanin, \& Conić, 2021), as well as privacy risk especially in online tourism purchase cases (González-Reverté, Díaz-Luque, Gomis-López, \& Morales-Pérez, 2018). The possible failure of personal data, that is, when details about a traveler are used without their knowledge or approval, is referred to as a privacy risk (Park \& Tussyadiah, 2017). Source and satisfaction risks (Turkmendag \& Uygur, 2020) have been mentioned in prior literature.

According to Caber et al. (2020), much more studies are needed to investigate the impact of risk on motivations of travel, assessments of destination image, and intention to visit. This study aims to examine tourists' risk perceptions regarding Turkey as a mixed-image destination and determine if the perceived risks about Turkey as a tourism destination change between first-time and repeat visitors (Karamustafa, Fuchs, \& Reichel, 2013). Meanwhile, the amount of risk perception may vary between countries and local destinations (Fuchs \& Reichel, 2006).

Some tourism studies have been conducted about the subjective risk perceptions of tourists particularly in destinations (Carballo, León, \& Carballo, 2017; Cetinsoz \& Ege, 2013; Deng \& Ritchie, 2018; Kozak et al., 2007; Mansfeld, Jonas, \& Cahaner, 2016; Osland et al., 2017; Ozascilar, Mawby, \& Ziyalar, 2019; Sert, 2019), focusing on country cases (Fuchs \& Reichel, 2006; Kırlar \& Ozgen, 2020; Sofiichuk, 2018) and other tourism sectors such as the hotel industry (Şen Küpeli \& Özer, 2020), purchasing online airline tickets (Kim, Kim, \& Leong, 2005), restaurants (Jin, Line, \& Merkebu, 2016), local festival visitors (Sohn, Lee, \& Yoon, 2016), and crises and disasters (Aliperti et al., 2019). Last year, with the emergence of the Covid-19 pandemic, travel risk research increased (Cetinkaya et al., 2020; Zhan, Zeng, Morrison, Liang, \& Coca-Stefaniak, 2020), including studies on how to reduce risks and types of risk reduction measures.

According to Rahman, Gazi, Bhuiyan, \& Rahaman (2021), the pandemic of Covid- 19 has had a significant impact on travel risk and management perceptions. At the same time, Seçilmiş et al., (2021), maintained that the association between trust and visit intention has been revealed to be moderated by Covid-19 anxiety. Additionally, Teeroovengadum, Seetanah, Bindah, Pooloo, \& 
Veerasawmy, (2021) were attempting to confirm the estimated influence of Covid-19 on the possibility of tourists visiting a destination based on perceived travel risk. Their findings revealed that perceived risk is likely to impact their decision to travel among visitors intending to travel in the aftermath of the Covid-19 pandemic. According to Teeroovengadum et al., (2021), there are six key fears for those with the capacity to reduce destination travel risk associated with Covid-19. These are the destination's Covid-19 situation, national sanitary measures, accommodation, health-care and transportation services and ecotourism facilities. Parallel to these studies, Rahman, Gazi, Bhuiyan, \& Rahaman, (2021) maintained that the Covid- 19 pandemic has had a significant impact on travel risk perceptions. Perception of risk in travel had a significant relationship with managing risk, delivery of services, transportation patterns, channels of distribution, avoidance of overcrowded destinations, hygiene, and safety. Meanwhile, Matiza, (2020) asserted that it is possible to predict the impact that the perceived risk associated with the pandemic will have on tourists' post-crisis behavior.

Asgarnezhad, Ebrahimpour, Zadeh, Banghinie, \& Soltani, (2018) mentioned that risk factors associated with tourism such as financial, economic, social and cultural, psychological, environmental, health, political, and technical hazards affect destination image. Furthermore, destination image is significant as a moderator in the link between all dimensions of tourism risk and foreign visitor satisfaction and loyalty.

Many researchers have tried to determine the dimensions of risk. However, risk not only consists of dimensions. While making a holiday decision, one's perception may also change before, during, and after the trip. This may vary depending on the first visit or the occurrence of many visits (Wolff et al., 2019). Meanwhile, studies have discussed the importance of measurement and definitions. In addition, the personal or sociodemographic characteristics of visitors may also affect their risk perceptions (Perić et al., 2021).

Tourists take some risks associated with their travel and destination choices (Supani \& Abd Hamid, 2020). Travelers have to consider risk factors when they choose destinations. Examples are unexpected situations such as terrorist attacks (Baumert, et al., 2020; Bayraktaroğlu, et al., 2021). The development of diseases and epidemics or other individual health problems as a result of tourism encounters is referred to as health risks (Chien, Sharifpour, Ritchie, \& Watson, 2017; Huang, Dai, \& Xu, 2020). Adverse weather conditions, public security, robberies, rape, and physical violence (Carballo et al., 2017) fall under physical risk, which is referred to as the likelihood of physical danger or injury to travelers (Khan, Khan, Amin, \& Chelliah, 2020).

The potential of tourists consuming tourism items for an excessive amount of time, i.e., time risk (Cui et al., 2016), and the likelihood of unplanned expenditure and financial loss ( $\mathrm{Lu}, 2021)$ may be realized only when the expected service performance falls short (Casidy \& Wymer, 2016).

Performance risk is defined as the loss incurred when services do not match the expected needs of travelers (Brack \& Benkenstein, 2014). It is therefore a quality-related risk (Keh \& Pang, 2010). According to Oliver (1980), if a product or service cannot meet the expectations of customers, risk factors arise particularly associated with travel decision-making (Korstanje, 2009).

Psychological risks that lead to damages to one's self-esteem or engender guilt consists of harm against self-image, discomfort with travel, and a feeling of unwanted anxiety during travel. In other words, individual travelers' 'disappointing travel experience' (Sönmez \& Graefe, 1998) and 'vacation will not reflect visitors' personality or self-image' (Simpson \& Siguaw, 2008).

Social risk refers to the perceived possibility of social loss (e.g., social embarrassment) (Casidy \& Wymer, 2016) or the the chance that a journey may not meet the expectations of others (travelers' family and friends) (Deng \& Ritchie, 2018), which is psychological. Thus, it is necessary to evaluate risk with both travelers and destinations.

Time risk refers to the waste of time to make the journey (Karamustafa et al., 2013), i.e., time consumed during the travel (Deng \& Ritchie, 2018). In this vein, scholars have investigated tourists' risk perception to advise destination and tourism cooperation policymakers (Cong, 2021; Dedeoğlu \& Boğan, 2021). Prior studies such as (Artuğer \& Kendir, 2014; Ateşoğlu \& Türker, 2013; Cetinsöz \& Ege, 2012; Fuchs \& Reichel, 2006; Koçoğlu, 2016) have identified six types (or dimensions) of perceived risk (Figure 1). 


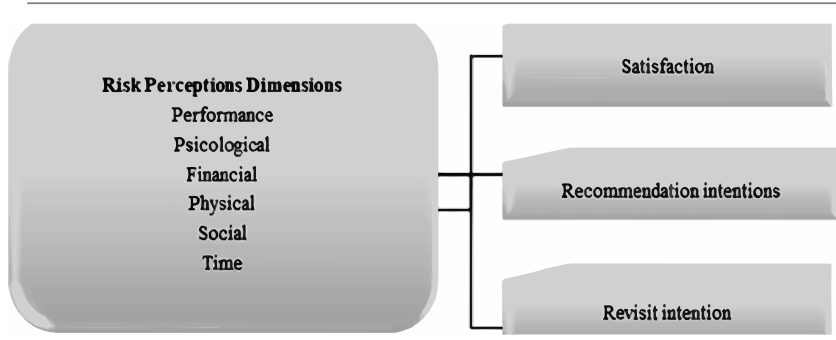

Source: Author

Figure 1. Study Design

\section{Satisfaction}

It is expected that many studies have attempted to quantify customer satisfaction, which is a key notion in tourism research. The higher the level of satisfaction among tourists, the greater their loyalty, recommendation, and consumption throughout their visit (Alrawadieh, Alrawadieh, \& Kozak, 2019; Alrawadieh, Prayag, Alrawadieh, \& Alsalameen, 2019; Huo \& Miller, 2007).

Oliver, (1999) described as the result of the consumption of a product or service to fulfill the preferences, demands, and requirements of customers. Guliling \& Aziz, (2018) asserted that satisfaction is a state of pleasure that results from meeting the demands of tourists. Formerly, customer satisfaction or dissatisfaction was measured by assessing the gap between consumer expectations and the actual situation as a result of consumption. This type of measurement is known as Oliver's expectation-disconfirmation model, which highlights the consumer's cognitive attitudes while excluding their emotional ones. That is to say, there are two major methods to analyzing tourist satisfaction: cognitive and emotional approaches. As in Oliver's expectancydisconfirmation paradigm, the cognitive approach includes post-experience evaluation. Oliver defined satisfaction as the gap between one's expectations and one's actual travel experience. (Tse \& Wilton, 1988), on the other hand, claimed that pre-visit expectation is not taken into account when evaluating satisfaction. As a result, independent of past expectations, satisfaction may be quantified; this is known as the emotional method. As a result, satisfaction is solely seen as an experience and psychological condition (Baker \& Crompton, 2000).

Cong, (2021) examined the direct impacts of risk perception on tourists' satisfaction and repurchase intentions. In other words, there is an adverse relationship between the risk perception of tourists and both satisfaction and loyalty. On the contrary, (Sohn et al., 2016) indicated that despite risk can cause people to have a poor view of a festival, it has no influence on satisfaction or future purchase intentions. The findings revealed that there is obvious causation between perception, satisfaction, and future intention. Not surprisingly, trust, customer satisfaction, and loyalty are all negatively affected by perceived risk (Jin et al., 2016). According to the conclusion of some studies, a high level of perceived risk reduces consumer satisfaction (Hasan et al., 2017). Consequently, it is hypothesized that:

$\mathrm{H} 1$ : There is a significant relationship between risk perception dimensions and general satisfaction, which is negatively affected by risk perception dimensions.

\section{Recommendation and Revisit Intentions}

Behavioral intentions are behavioral tendencies in line with the evaluations of individuals' knowledge, emotions, and experiences (Savaşçı \& Yıldırım, 2021). Recommendation intention and willingness to return are two important positive behavioral intentions for destination loyalty (i.e., revisit intention or revisit behavior) ( $\mathrm{Lv}, \mathrm{Li}, \& \mathrm{McCabe}$, 2020). The probability of a visitor returning to a destination is referred to as revisit intention (Chen, Cheng, \& Kim, 2020). That is "intention to revisit is the willingness to visit a destination again" (Soleimani \& Einolahzadeh, 2018). "Repurchase behavior is a measure of consumers' reactions as a result of certain experiences" (Turkmendag \& Uygur, 2020). In addition, Chen and Tsai (2007) identified travelers' behavioral intention as their assessment of the likelihood of returning to destination and recommending them to others. In the context of risk perception of visitors, a number of prior studies have revealed that risk perception of tourists may affect negatively re-visit (Tosun, Dedeoğlu, \& Fyall, 2015) and recommendation intentions (Choo, Choo, \& Kang, 2016; Nazir, Yasin, \& Tat, 2021).

It is almost certain that perceived risk factors that influence a person's decision to travel significantly affect their satisfaction, and willingness to return, i.e., tourists' behavioral intentions (Fourie, et al., 2020; Xie, Zhang, \& Morrison, 2021). It is reported that the intention to revisit and recommend is significantly affected by perceived risk factors, similar to the concept of satisfaction. For example, Artuğer, (2015) found that visitors' perceptions of risks during their vacation in Marmaris influence their desire to return.

In addition, Chew \& Jahari, (2014) examined the function of destination image in moderating the connection between perceived risks and repeat travelers' desire to return. Their study investigated 
the mediating effects of two types of destination images-cognitive and emotional-on the connection between perceived risks (physical, sociopsychological, and financial) and the desire to return. Parallel results can be observed in a study by Cetinsoz and Ege (2013). The influence of perceived risk levels concerning Alanya on return intention was evaluated using correlation and regression analysis. Several key risk dimensions were identified from the investigation, and it was discovered that some of them influenced their return.

Opposite the many risks during travel, positive psychology and visitor well-being have had behavioral implications that in turn affect repeat visitation, positive word-of-mouth (WOM) which has been revealed to be an important element in service marketing. This has been associated with reductions in consumer risk (Dedeoglu, Bilgihan, Ye, Buonincontri, \& Okumus, 2018), and destination attachment (Vada, Prentice, Scott, \& Hsiao, 2020). Also, Sert (2019) stated that perceived safety was observed to have an impact on risk reduction behavior, recommendation, and revisit intention. Similar result is observed in the study of (Hasan et al., 2017). They maintained that high level of perceived risk negatively influences customer repurchase intention.

Using these as a departure point, the following research hypotheses are proposed:

H2: There is a significant relationship between risk perception dimensions and revisit intention, which is negatively affected by risk perception dimensions.

H3: There is a significant relationship between risk perception dimensions and recommendation intention, which is negatively affected by risk perception dimensions.

The aforementioned hypotheses are on the basis of theory of planned behavior which is based on the assumption that behaviors are based on a certain cause. According to theory, people think in advance about the consequences of their behavior, come to a decision to reach a result they choose, and implement this decision. In other words, behaviors occur as a result of a certain intention (Quintal, Lee, \& Soutar, 2010). This intention achieves the result that was previously thought. As a result the subjective expectations, also associated with risk, could significantly impact consumer's behavior (Demirel \& Ciftci, 2020; Huang, et al., 2020; Pelaez et al., 2019; Quintal et al., 2010). People's perceptions of risk are likely to influence their future travel decisions (Quintal et al., 2010). Based on the theory of planned behavior, the process of making a choice on future behavior is influenced by one's attitude toward the behavior, which is shaped by one's beliefs (is it beneficial or harmful). As a result, risk perception of visitors may affect their future behavioral intention (Gstaettner, Rodger, \& Lee, 2017).

\section{Materials and Method}

The current investigation involved risk perceptions of domestic visitors and the effects of satisfaction and re(visit) and recommendation intentions. The site was selected from the cultural and historic city of Sanliurfa, which is located southeast of Turkey. Due to the pandemic conditions, the survey form was sent online to the visitors. A total of 471 respondents were collected via convenience sampling method among domestic tourists from May to June 2021 and answered an online questionnaire. Sample size was calculated with the help of the following formula as minimum 384:

$$
n=\frac{N t^{2} p q}{d^{2}(N-1)+t^{2} p q}
$$

Where n: number of sample size, $\mathrm{N}$ : number of populations, $\mathrm{t}$ : $\mathrm{Z}$ value within $\% 95$ confidence interval as 1.96 , p: probability of tourists to visit site 0.50 , q: 1-p: 0.50 , probability of not to visit $d$ : margin of error 0,05 (Yamane, 2006).

The questionnaire has two main parts. The first covers visitors' personal characteristics such as gender, age, education level, occupation, etc. The second consists of a five-point Likert scale ranging from 1 (strongly disagree) to 5 (strongly agree); it was used to measure the risk dimensions of visitors. This scale consists of six dimensions, namely, physical, time, social, performance, financial, and psychological risks, which consist of 28 items. The perceived risk scale was adapted from the studies of (Fuchs \& Reichel, 2006) and (Artuğer \& Kendir, 2014). In addition, the scale used in the study contains three items that measure general satisfaction, two items that measure recommending behavior, and three items that measure revisiting intention. The measures were adapted from (Hosany, Prayag, Deesilatham, Cauševic, \& Odeh, 2015) study.

In the study, the Kaiser-Meyer-Olkin (KMO) coefficient was used to determine whether the sample was sufficient, and Barlet's test was performed to determine whether the structure was significant. According to the result of Barlet's test, the structure is significant (Barlet's X2 $=1645.28$, $\mathrm{p}=0.01)$. This shows that the 471 participants 
included in the study are sufficient for the evaluation of the scale. Correlation and regression analysis were performed to examine the relationships between risk levels, overall satisfaction, recommendation, and repeat behavior. To test the internal consistency of the dimensions, Cronbach's alpha coefficient was calculated. Analyses were made using SPSS 25.0.

To test the hypotheses, a regression model was adopted. This is a method that examines the relationship between a dependent variable and one or more independent variables (Gujarati, 2004). Three different models were created in the study. In these models, satisfaction, recommendation, and revisit intentions were the dependent variables, while performance, psychological, financial, physical, social, and time values were the independent variables. The models used in the study are shown in Table 1.

Table 1. Models

\begin{tabular}{|l|l|l|}
\hline Models & Dependent Variables & $\begin{array}{l}\text { Independent } \\
\text { Variables }\end{array}$ \\
\hline Model 1 & Satisfaction (sat) & $\begin{array}{l}\text { Performance } \\
\text { Psychological } \\
\text { Financial } \\
\text { Physical } \\
\text { Social } \\
\text { (rec) }\end{array}$ \\
\cline { 1 - 2 } $\begin{array}{l}\text { Model } \\
\text { III }\end{array}$ & Revisit intention (rev)
\end{tabular}

As a result of the Kolmogorov Smirnov test, the data are normally distributed. In other words, distributions of Physical, Psychological, Financial, Time, Performance and Social risk dimensions were normal according to Kolmogorov Smirnov test (KS p>0.05). In addition, skewness and kurtosis values were checked for normal distribution. It was observed that the skewness and kurtosis values of the dimensions were between -1 and 1 , which are acceptable limits. The fact that the number of participants in the study was at a high level, such as 471 , was thought to be appropriate for normal distribution. The distributions of the dimensions of General Satisfaction, Recommendation and Revisit Intent were normal (KS p>0.05). Thus, it would be more appropriate to apply normal tests in the analyzes. The averages of the dimensions are as follows: Physical Risk average was $3.25 \pm 0.67$, Psychological Risk average was $3.88 \pm 0.82$, Financial Risk average was $3.86 \pm 0.77$, Time Risk average was $3.89 \pm 0.85$, Performance Risk average was $3.35 \pm 0.75$ and Social risk dimension occurred at the average of $4.23 \pm 0.76$. It was determined that the General Satisfaction mean was $2.73 \pm 0.53$, the Recommendation mean was $2.02 \pm 0.90$, and the Revisit Intention mean was $2.03 \pm 0.92$ (Table 2).
Table 2: Dimension Scores and Normality Tests

\begin{tabular}{|c|c|c|c|c|c|c|}
\hline Dimensions & $\begin{array}{c}N \\
\tilde{N}\end{array}$ & $\begin{array}{l}\tilde{U} \\
\tilde{\theta}\end{array}$ & $x$ & $\dot{\vec{g}}$ & 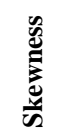 & $\frac{\mathscr{n}}{\mathscr{E}}$ \\
\hline Physical Risks & 0.07 & 0.14 & 3.25 & 0.67 & -0.20 & 0.11 \\
\hline Psychological Risks & 0.07 & 0.07 & 3.88 & 0.82 & 0.11 & 0.22 \\
\hline Financial Risks & 0.05 & 0.23 & 3.86 & 0.77 & 0.42 & 0.34 \\
\hline Time Risks & 0.08 & 0.06 & 3.89 & 0.85 & 0.73 & 0.45 \\
\hline Performance Risks & 0.08 & 0.05 & 3.35 & 0.75 & 0.04 & 0.56 \\
\hline Social Risks & 0.06 & 0.18 & 4.23 & 0.76 & 0.35 & 0.67 \\
\hline General Satisfaction & 0.07 & 0.13 & 2.73 & 0.53 & 0.65 & 0.79 \\
\hline $\begin{array}{l}\text { Recommendation } \\
\text { Intention }\end{array}$ & 0.03 & 0.29 & 2.02 & 0.90 & 0.96 & 0.90 \\
\hline Revisit Intention & 0.06 & 0.17 & 2.03 & 0.92 & 0.07 & 0.01 \\
\hline
\end{tabular}

Source: Author

\section{Findings}

\section{Characteristics of Participants}

Of the 471 valid respondents, $55.4 \%$ were married and $44.6 \%$ were single, while $57.1 \%$ were male and $42.9 \%$ were female. Out of the sample, $42.9 \%$ were aged 25-34, and 29.5\% were aged 35-44. Around $86.6 \%$ finished university education and above. The participants were public servants (50.5\%) and students (17.2\%) (Table 3).

Table 3. Descriptive Analysis of Respondents

\begin{tabular}{|c|c|c|c|}
\hline & & n & $\%$ \\
\hline \multirow{2}{*}{ Marital status } & Married & 261 & 55.4 \\
\hline & Single & 210 & 44.6 \\
\hline \multirow{2}{*}{ Gender } & Female & 269 & 57.1 \\
\hline & Male & 202 & 42.9 \\
\hline \multirow{6}{*}{ Age } & $18-24$ & 94 & 20.0 \\
\hline & $25-34$ & 202 & 42.9 \\
\hline & $35-44$ & 139 & 29.5 \\
\hline & $45-54$ & 28 & 5.9 \\
\hline & $55-64$ & 5 & 1.1 \\
\hline & 65 and over & 3 & 0.6 \\
\hline \multirow{6}{*}{ Education } & Without education & 3 & 0.6 \\
\hline & Primary & 2 & 0.4 \\
\hline & Middle & 10 & 2.1 \\
\hline & College & 48 & 10.2 \\
\hline & University & 342 & 72.6 \\
\hline & Master and Ph.D. & 66 & 14.0 \\
\hline \multirow{8}{*}{ Occupation } & Public servant & 238 & 50.5 \\
\hline & Student & 81 & 17.2 \\
\hline & Civil servant & 9 & 1.9 \\
\hline & Worker & 36 & 7.6 \\
\hline & Retired & 5 & 1.1 \\
\hline & Business & 13 & 2.8 \\
\hline & Jobless & 34 & 7.2 \\
\hline & Other & 55 & 11.7 \\
\hline
\end{tabular}

Source: Author

Cronbach's alpha was 0.93 , showing that the scale was reliable. Thus, there was no need to remove 
Table 4. Destination Risk Dimensions, Variance, and Internal Consistency

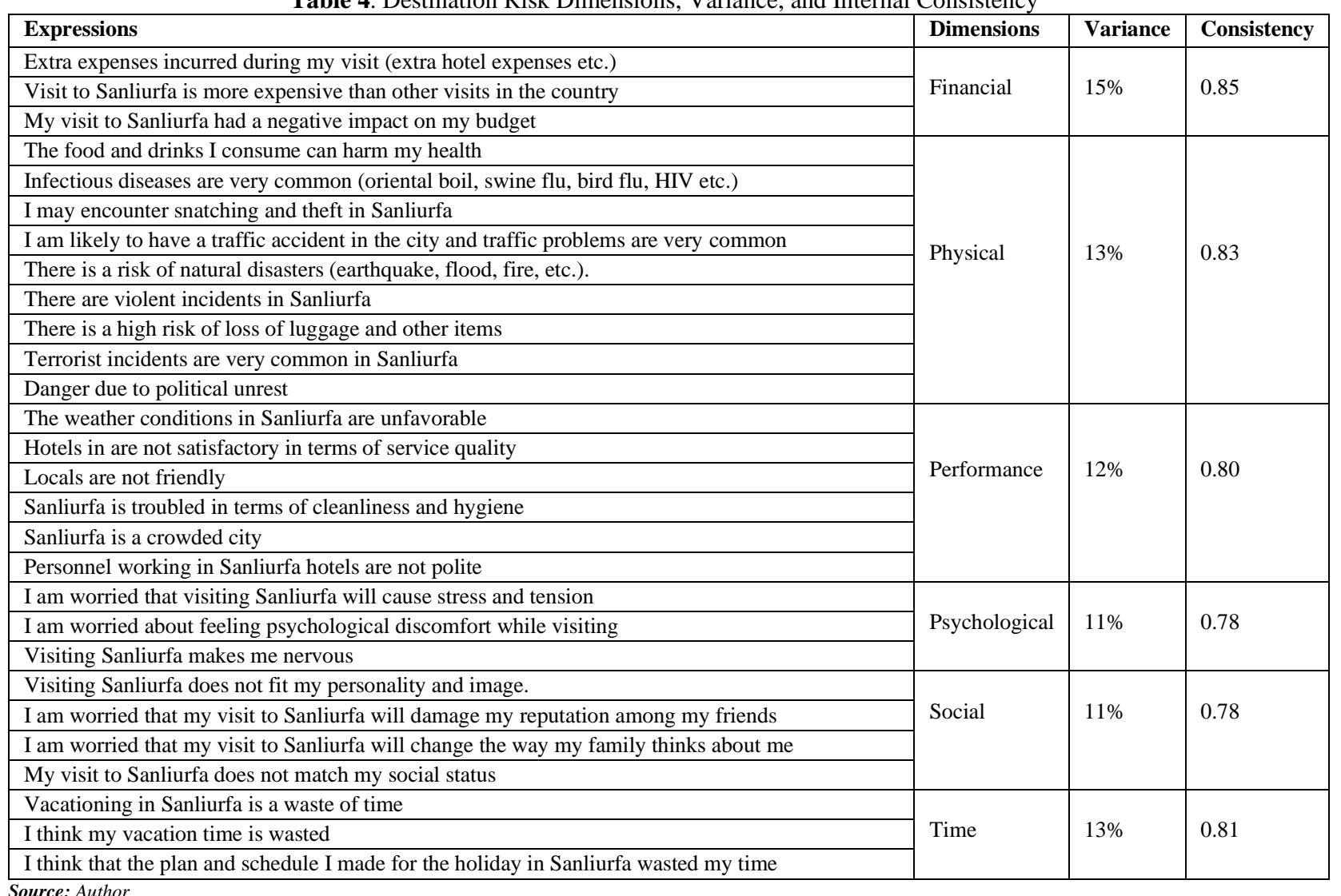

statements from the scale to increase reliability. The six dimensions were identified in their original form and constituted approximately $62 \%$ of the total variance. The explained variance percentage of the financial dimension was $15 \%$, internal consistency 0.85 ; physical dimension $13 \%, 0.83$; performance risk $12 \%, 0.80$; psychological $11 \%$, 0.78 ; social 11\%, 0.78; and time $13 \%, 0.81$ (Table 4). The KMO level was 0.89 ; thus, the sample size was sufficient. The structure was significant (Barlet's $\mathrm{X} 2=1645.28, \mathrm{p}=0.01)$. This shows that the 471 participants included in the study were enough for the evaluation of the scale.

All dimensions namely, satisfaction, recommendation and revisit intentions are reliable. Table 5 shows their expressions, dimensions, explained variance and reliability.
Examining the Relationships between Risk Perceptions and General Satisfaction, Recommendation, and Revisit Intention

In the study, correlation analysis was conducted to examine the relationships between participants' risk perception dimensions and their general satisfaction and recommendation and revisit intentions (Table 6). There was a weak inverse and significant relationship between the performance, social, physical, psychological, financial, and time risk dimensions and satisfaction level. Meanwhile, there was a moderately strong, inverse, and significant relationship between all dimensions of risk perception and recommendation and revisit intentions.

Table 5. Reliability of Satisfaction, Recommendation, and Revisit Dimensions

\begin{tabular}{|c|c|c|c|}
\hline Expressions & Dimensions & Explained Variance & Reliability \\
\hline Overall, Sanliurfa visit was a mistake for me & \multirow{3}{*}{ Satisfaction } & \multirow{3}{*}{$49 \%$} & \multirow{3}{*}{0.80} \\
\hline Overall, a visit to Sanliurfa is a loss for me. & & & \\
\hline Overall, I was satisfied with the Sanliurfa visit & & & \\
\hline I will recommend my friends and family to visit Sanliurfa. & \multirow[t]{2}{*}{ Recommendation } & \multirow[t]{2}{*}{$43 \%$} & \multirow[t]{2}{*}{0.77} \\
\hline I tell positive things about Sanliurfa to others & & & \\
\hline There is a high probability that I will come to Sanliurfa again. & \multirow{3}{*}{ Revisit } & \multirow{3}{*}{$45 \%$} & \multirow{3}{*}{0.79} \\
\hline Sanliurfa is a safe city that I can visit again & & & \\
\hline I would like to come to Sanliurfa again because it is worth coming & & & \\
\hline
\end{tabular}


Journal of multidisciplinary academic tourism 2022, 7 (1): 81-96

Table 6. Examining the Relationships between Risk Perceptions and General Satisfaction, Recommendation and Revisit Intention

\begin{tabular}{|c|c|c|c|c|}
\hline 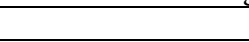 & & Overall satisfaction & Recommendation intentions & Revisit intentions \\
\hline \multirow{2}{*}{ Physical risks } & $\mathrm{r}$ & $-0.25^{*}$ & $-0.44^{*}$ & $-0.44^{*}$ \\
\hline & $p$ & 0.01 & 0.01 & 0.01 \\
\hline \multirow{2}{*}{ Psychological risks } & $\mathrm{r}$ & $-.023^{*}$ & $-0.55^{*}$ & $-0.58^{*}$ \\
\hline & $p$ & 0.01 & 0.01 & 0.01 \\
\hline \multirow{2}{*}{ Financial risks } & $\mathrm{r}$ & $-0.21^{*}$ & $-0.49^{*}$ & $-0.43^{*}$ \\
\hline & $p$ & 0.01 & 0.01 & 0.01 \\
\hline \multirow{2}{*}{ Time risks } & $\mathrm{r}$ & $-0.24^{*}$ & $-0.59^{*}$ & $-0.57^{*}$ \\
\hline & $p$ & 0.01 & 0.01 & 0.01 \\
\hline \multirow{2}{*}{ Performance risks } & $\mathrm{r}$ & $-0.22^{* *}$ & $-0.53^{*}$ & $-0.51^{*}$ \\
\hline & $p$ & 0.01 & 0.01 & 0.01 \\
\hline \multirow{2}{*}{ Social Risk } & $\mathrm{r}$ & $-0.34^{*}$ & $-0.40^{*}$ & $-0.43^{*}$ \\
\hline & $p$ & 0.01 & 0.01 & 0.01 \\
\hline
\end{tabular}

Source: Author

All risk dimensions negatively affect overall satisfaction and recommendation and revisit intentions. However, risk levels affect recommendation and revisit levels more. The level of satisfaction is less negatively affected by risks.

Examining the Effects of Risk Perceptions on the Levels of General Satisfaction and Recommendation and Revisit Intention

The model determined between the physical, time, performance, and psychological risk dimensions of general satisfaction was significant $(\mathrm{F}=21.53, \mathrm{p}=$ $0.01, \mathrm{p}<0.05)$. The percentage of explanation of the model was $44 \%(\mathrm{R} 2=0.44)$, which was high. The coefficients of the physical, time, performance, and psychological risk dimensions were also found to be significant $(p=0.01, p<0.05)$. According to the results of the Durbin Watson test, there was no autocorrelation in the model (D.W.: 1.88). As a result, the model was found to be significant. The model obtained as a result of the analysis was as follows:

General satisfaction $(Y)=(-0.14) *$ Physical Risks $(-0.26)$ * Time Risk (-0.13) * Performance Risk (-0.15) * Psychological Risks

According to the results, the risk that most affected the general satisfaction level was time risk. An increase in time risk by one unit means that the general satisfaction level will decrease by 0.26 units. Then, performance risk, physical risk, and psychological risk were ranked according to their level of impact. Although weaker than the effect of time risk, the increase in performance risk, physical risk, and psychological risk perceptions will decrease general satisfaction by $0.13-0.15$ units (Table 7).
Table 7. Risk Perceptions and General Satisfaction

\begin{tabular}{|c|c|c|c|c|c|c|}
\hline \multicolumn{5}{|c|}{ Independent variables } & \multirow{3}{*}{$\mathbf{F}_{\text {Model }}$} & \multirow{3}{*}{$\mathbf{R}^{2}$} \\
\hline \multirow{2}{*}{ 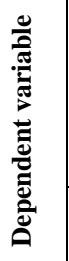 } & 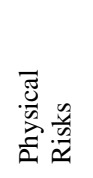 & $\begin{array}{l}\frac{\tilde{u}}{\vec{n}} \\
\vec{\Xi} \\
\stackrel{\Xi}{\Xi}\end{array}$ & 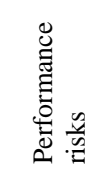 & 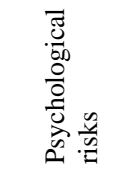 & & \\
\hline & $(\beta)$ & $(\beta)$ & $(\beta)$ & $(\beta)$ & & \\
\hline \multirow{2}{*}{ 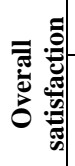 } & -0.14 & -0.26 & -0.13 & -0.15 & 21,53 & \multirow[b]{2}{*}{0.44} \\
\hline & $\mathrm{p}=0.01$ & $\mathrm{p}=0.01$ & $\mathrm{p}=0.01$ & $\mathrm{p}=0.01$ & $\mathrm{p}=0.01$ & \\
\hline
\end{tabular}

** Regression analysis applied, D.W;1,88

Source: Author

significant $(\mathrm{F}=107.52, \mathrm{p}=0.01, \mathrm{p}<0.05)$. The percentage of explanation of the model was $64 \%$ $(\mathrm{R} 2=0.64)$, which was high. The coefficients of time, psychological, and financial risk dimensions were also found to be significant $(p=0.01, p<0.05)$. According to the results of the Durbin Watson test, no autocorrelation existed in the model (D.W.: 1.93). As a result, the model was found to be significant. The model obtained as a result of the analysis was as follows:

Recommend $(Y)=(-0.14) *$ Time Risk $(-0.26)$ * Psychological Risk (-0.13) * Financial Risk

Table 8. Risk perceptions and recommendation intention

\begin{tabular}{|c|c|c|c|c|c|}
\hline \multicolumn{4}{|c|}{ Independent variables } & $\mathrm{F}_{\text {Model }}$ & \multirow[t]{3}{*}{$\mathrm{R}^{2}$} \\
\hline & $\begin{array}{l}\text { Time } \\
\text { risks }\end{array}$ & $\begin{array}{l}\text { Psychological } \\
\text { risks }\end{array}$ & $\begin{array}{l}\text { Financial } \\
\text { risks }\end{array}$ & \multirow{2}{*}{107.52} & \\
\hline $\begin{array}{l}\text { Dependent } \\
\text { variable }\end{array}$ & $(\beta)$ & $(\beta)$ & $(\beta)$ & & \\
\hline \multirow{2}{*}{$\begin{array}{l}\text { recommendation } \\
\text { intention }\end{array}$} & -0.14 & -0.26 & -0.13 & & \multirow{2}{*}{0.64} \\
\hline & $\mathrm{p}=0,01$ & $\mathrm{p}=0.01$ & $\mathrm{p}=0.01$ & $\mathrm{p}=0.01$ & \\
\hline
\end{tabular}

** Regression analysis applied, D.W;1,93

Source: Author

The model determined between time and psychological risk dimensions and revisit intention were significant $(F=158.30, p=0.01, p<0.05)$. The percentage of explanation of the model was $41 \%$ $(\mathrm{R} 2=0.41)$, and this rate was high. The coefficients 
of the dimensions of time and psychological risks were also found to be significant $(p=0.01, p<0.05)$. According to the results of the Durbin Watson test, no autocorrelation is present in the model (D.W.: 1.85). As a result, the model was found to be significant. The model obtained as a result of the analysis was as follows:

Revisit intention $(\mathrm{Y})=(-0.34) *$ Time Risk $(-0.36)$ * Psychological Risk

According to the results, the risk that most affected the level of revisit was psychological risk. An increase in psychological risk level by one unit means that the level of revisit will decrease by 0.36 units. Increasing the time risk level by one unit will decrease the recommendation level by 0.34 units.

Table 9. Risk perceptions and recommendation intention

\begin{tabular}{|l|l|l|l|l|}
\hline & \multicolumn{2}{|l|}{ Independent variables } & $\mathbf{F}_{\text {Model }}$ & $\mathbf{R}^{\mathbf{2}}$ \\
\hline \multirow{2}{*}{$\begin{array}{l}\text { Dependent } \\
\text { variable }\end{array}$} & $\begin{array}{l}\text { Psychological } \\
\text { risks }\end{array}$ & Time risks & 158.30 & \\
\cline { 2 - 4 } & $(\beta)$ & $(\beta)$ & & \\
\hline \multirow{2}{*}{$\begin{array}{l}\text { Revisit } \\
\text { intention }\end{array}$} & -0.36 & -0.34 & & \multirow{2}{*}{0.41} \\
\cline { 2 - 4 } & $\mathrm{p}=0.01$ & $\mathrm{p}=0.01$ & $\mathrm{p}=0.01$ & \\
\hline
\end{tabular}

The overall satisfaction levels of the participants were highly correlated with their recommendation level and revisit intention. It can be predicted that the recommendation levels of participants with high general satisfaction levels will also be high ( $p$ $=0.62, \mathrm{p}=0.01)$. It can also be projected that participants with high general satisfaction levels will also have high revisit intentions $(p=0.65, p=$ 0.01). The recommendation levels of the participants were highly correlated with their level of revisit intention. This predicts that participants with high recommendation levels will also have high revisit intentions $(p=0.78, p=0.01)$.

Table 10. Correlations between dependent variables

\begin{tabular}{|l|c|l|l|l|}
\hline \multicolumn{2}{|l|}{ Dimentions } & $\begin{array}{l}\text { Overall } \\
\text { Satisfaction }\end{array}$ & $\begin{array}{l}\text { Recommendation } \\
\text { intention }\end{array}$ & $\begin{array}{l}\text { Revisit } \\
\text { intention }\end{array}$ \\
\hline $\begin{array}{l}\text { Overall } \\
\text { Satisfaction }\end{array}$ & r & 1 & & \\
\hline & p & & & \\
\hline $\begin{array}{l}\text { Recommendation } \\
\text { intention }\end{array}$ & r & $0.62^{*}$ & 1 & \\
\hline & p & 0.01 & & \\
\hline \multirow{2}{*}{ Revisit intention } & r & $0.65^{*}$ & $0.78^{* *}$ & 1 \\
\cline { 2 - 5 } & p & 0.01 & 0.01 & \\
\hline Source: Author & \multicolumn{4}{|l}{} \\
\hline
\end{tabular}

\section{Discussion and Conclusion}

Perceived risk is a concept that affects the purchasing decision process of customers (Ateşoğlu \& Türker, 2013b). Particularly, the risks perceived by tourists about the destinations affect destination selection processes (Ritchie \& Jiang, 2019; Ünal, 2020). Because of perceived risks, a significant percentage of visitors were able to cancel and postpone vacation plans to a variety of places (Cetinsoz \& Ege, 2013). Hence, familiarity with visitor attitudes can help preserve the sustainability of a tourism destination (Sohn et al., 2016). Additionally, satisfaction, recommendation to others, and repeat visitation intention of visitors play essential roles in promoting destination attractions. Thus, it is important to determine the perceived risk of tourists associated with destinations and countries.

Under these circumstances, the first aim of this article was to examine the risk dimensions of domestic tourists visiting Sanliurfa. After examining the dimensions, the study aimed to evaluate the relationship between the overall satisfaction, recommendation intention, repurchase behavior variables, and risk perception of visitors. In other words, the present study's goal was to determine the effects of risk perceptions on the aforementioned variables. Identifying risk may assist tourism and hospitality organizations to gain a competitive advantage, as eliminating or decreasing customers' risk perceptions helps tourist and hospitality businesses attract and keep customers (Koc \& Villi, 2021). As a result, the evaluation of risk perceptions is valuable for both destination managers and visitors.

First, the study revealed six dimensions of risk perceptions as those of previous similar studies (Artuğer, 2015). He stated that the risk perception of tourists has five dimensions, which are sociopsychological, time, financial, and performance risks, which are parallel to those of the current study. The conclusion from this study is similar to that in (Karamustafa et al., 2013), whose findings revealed six risk dimensions including time and social, financial, physical risks, etc. However, this study provided little evidence to support the findings of an earlier study by (Zhan et al., 2020), who pointed out that a risk perception scale has only four dimensions (health, financial, social, and performance). Their study differed from the present one with the omission of physical and time dimensions. As a result, theoretically, the study validated the six dimensions of risk as in the studies of Ateşoğlu and Türker (2013), Fuchs and Reichel (2006), Koc and Villi (2020), and Artuğer and Kendir (2014). Moreover, some researchers asserted that there are other factors affecting risk perceptions; for example, (Çetinsöz, 2011) introduced five factors: satisfaction, time, physical, social-physiological, functional, or operational risks, namely, performance risk. In conclusion, the risk perception of visitors usually includes five or six dimensions. These can be seen in detail in Cui 
et al. (2016), which provided an overview of tourism risk perception.

Second, consistent with prior research in tourism (Asgarnezhad et al., 2018; Casidy \& Wymer, 2016), this study provided empirical evidence of a link between satisfaction and all risk dimensions except financial and social risks. Financial, social, performance, and psychological risks have substantial reverse effects on satisfaction (Casidy \& Wymer, 2016). Meanwhile, (Asgarnezhad et al., 2018) found a connection between all dimensions of travel risk and international visitors' satisfaction and revisit and recommendation intentions. Cong (2021) examined the direct impact of perceived risk on tourist satisfaction and loyalty. A similar pattern of results was found by Nguyen Viet, Dang, and Nguyen (2020) in that satisfaction is directly affected by perceived risk. But the conclusion of this study differs from that of Sohn et al. (2016), who stated that although risk can cause people to have a poor view of a festival, it has no impact on satisfaction or future purchase intentions. Finally, the findings indicated an inverse link among perceived risks and customer purchase decisions (Li et al., 2020). In addition, several researchers have found that a high degree of risk perception reduces the satisfaction of customers and therefore has a negative impact on customer repurchase intent (Beneke, Flynn, Greig, \& Mukaiwa, 2013; Jin et al., 2016; Li \& Murphy, 2013).

Theoretical studies have revealed that risk perceptions have a strong negative influence on repeat behavior, particularly time and psychological dimensions. As identified by (Cetinsoz \& Ege, 2013), there is a correlation between risk perception and repeat purchase intention. Although the current paper states that only time and psychological risks affect revisit intention, Cetinsoz and Ege (2013) pointed out that physical, satisfaction, and time risk dimensions impact the willingness to return. They discovered that the social, psychological, and performance risk dimensions had no effect on visitors' desire to return to Alanya.

$\mathrm{Lu}$, (2021) asserted that the perception of environmental risk has a substantial influence on return intention, but sociopsychological risk enhances revisit intention. Additionally, tourists who perceived a low risk of these natural catastrophes had a higher favorable destination image, overall satisfaction, and behavioral intention than those who perceived a high risk (Tavitiyaman \& $\mathrm{Qu}, 2013$ ). In contrast, it was observed that perceived risk had no effect on behavioral intention (Savaşçı \& Yıldırım, 2021). Similar results can be seen in the study of (Sohn et al., 2016), who showed that although risk might contribute to an unfavorable perception of a festival, it has no influence on satisfaction or future purchase behavior. Along with their findings, there is a straightforward correlation among perception, satisfaction, and future intention. In accordance with the literature (i.e., (Sohn et al., 2016), risk perception was negatively linked with all other factors, while all other variables were positively correlated with each other.

Third, the results of the study indicated a weak inverse and significant relationship between the performance, social, physical, psychological, financial, and time risk dimensions and participants' perception and general satisfaction levels. These results were confirmed by $\mathrm{Li}$ and Murphy (2013), who found that risk factors might have an adverse influence on customer satisfaction. Meanwhile, there is a moderately strong, inverse, and significant relationship between all dimensions of participants' risk perception and their recommendation and revisit intention. Thus, perceptions of risk dimensions have a strong negative influence on overall satisfaction and recommendation and revisit intentions (Hasan et al., 2017).

Fourth, by employing three regression models, the present study reported that time and psychological risks highly affect all dependent variables. Furthermore, overall satisfaction was significantly affected by physical and performance dimensions. Recommendation intention was affected by the financial dimension beyond the aforementioned dimensions. Finally, the overall satisfaction levels of the participants were highly correlated with their recommendation levels and revisit intention. At the same time, their recommendation intention was highly correlated with their revisit intention.

The present study implies that because of the various significant influences on customer loyalty, (i.e., repeat visitation and recommendation intention), time, psychological, and financial risk dimensions should be given strict consideration by destination marketers. The findings support the ideas of some studies such as Cetinsoz and Ege (2013). The study's conclusions can help with effective marketing and promotion initiatives to satisfy the needs of tourists.

One of the limitations of the study is that it considered the "effects of the tourists' past experiences on the behavioral intention" (Fuchs \& 
Reichel, 2006), while some research collected data from visitors before purchasing travel (Qi, Gibson, \& Zhang, 2009). Another limitation of this study is the limited coverage of the effect of the recent pandemic conditions on visitor behavior. In future research, international tourists' perceived risk dimensions can be evaluated. This paper may contribute knowledge especially to tourist and tourism service operators as guidelines on how to manage risks as well as ensure the sustainability of the business.

\section{References}

Aliperti, G., Sandholz, S., Hagenlocher, M., Rizzi, F., Frey, M., \& Garschagen, M. (2019). Tourism, crisis, disaster: an interdisciplinary approach. Annals of Tourism Research, 79, 102808. https://doi.org/10.1016/j.annals.2019.102808

Alrawadieh, Z., Alrawadieh, Z., \& Kozak, M. (2019). Exploring the impact of tourist harassment on destination image, tourist expenditure, and destination loyalty. Tourism Management, 73(January), 13-20. https://doi.org/10.1016/j.tourman.2019.01.015

Alrawadieh, Z., Prayag, G., Alrawadieh, Z., \& Alsalameen, M. (2019). Self-identification with a heritage tourism site, visitors' engagement and destination loyalty: the mediating effects of overall satisfaction. Service Industries Journal, 2069 .

https://doi.org/10.1080/02642069.2018.1564284

An, M., Lee, C., \& Noh, Y. (2010). Risk factors at the travel destination: their impact on air travel satisfaction and repurchase intention. Service Business, 4(2), 155-166. https://doi.org/10.1007/s11628-010-0094-2

Artuğer, S. (2015). The Effect of Risk Perceptions on Tourists ' Revisit Intentions. European Journal of Business and Management, 7(2), 36-43.

Artuğer, S., \& Kendir, H. (2014). Yerli Turistlerin Destinasyon Risk Algllamaları: Afyonkarahisar İli Örneği. In 1. International Congress of Tourism and Management Researches.

Ateşoğlu, İ., \& Türker, A. (2013). Türkiye'de tatil yapan turistlerin algıladıkları risk türleri. Seyahat ve Otel İsletmeciliği Dergis, 10(3), 24-44.

Baker, D. A., \& Crompton, J. L. (2000). Quality, satisfaction and behavioral intentions. Annals of Tourism Research, 27(3), 785-804. https://doi.org/10.1016/S0160-7383(99)00108-5

Baumert, T., de Obesso, M. M., \& Valbuena, E. (2020). How does the terrorist experience alter consumer behaviour? An analysis of the Spanish case. Journal of Business Research, 115(June), 357364. https://doi.org/10.1016/j.jbusres.2019.11.085
Bayraktaroğlu, E., Gürsoy, S., Günay, F., \& Karakuş, Y. (2021). Geopolitical Risks and International Tourist Arrivals to Turkey: a Causality Study. Anais Brasileiros De Estudos Turísticos - ABET, 11. https://doi.org/10.5281/zenodo.5771032

Beneke, J., Flynn, R., Greig, T., \& Mukaiwa, M. (2013). The influence of perceived product quality, relative price and risk on customer value and willingness to buy: a study of private label merchandise. Journal of Product \& Brand Management, 22(3), 218-228

Bettman, J. R. (1973). Perceived Risk and Its Components: A Model and Empirical Test. Journal of Marketing Research, 10(2), 184. https://doi.org/10.2307/3149824

Caber, M., González-Rodríguez, M. R., Albayrak, T., \& Simonetti, B. (2020). Does perceived risk really matter in travel behaviour? Journal of Vacation Marketing, 26(3), 334-353. https://doi.org/10.1177/1356766720927762

Carballo, R. R., León, C. J., \& Carballo, M. M. (2017). The perception of risk by international travellers. Worldwide Hospitality and Tourism Themes, $9(5)$, 534-542. https://doi.org/10.1108/WHATT-072017-0032

Casidy, R., \& Wymer, W. (2016). A risk worth taking: Perceived risk as moderator of satisfaction, loyalty, and willingness-to-pay premium price. Journal of Retailing and Consumer Services, 32, 189-197.

https://doi.org/10.1016/j.jretconser.2016.06.014

Cetinkaya, O., Ozer, Y., \& Altuner, G. (2020). Evaluation of touristic travel risk perception and hygienesafety perception in the Covid-19 process. Tourism and Recreation, 2(2), 78-83.

Çetinsöz, B. C. (2011). Uluslararası Seyahatlerde Turistlerin Cekim Yerinde Alglladıkları Risklerin Tekrar Ziyaret Etme Niyetlerine Etkileri. Adnan Menderes Üniversitesi, Sosyal Bilimler Enstitüsü, Turizm İşletmeciliği Anabilim Dalı.

Cetinsoz, B. C., \& Ege, Z. (2013). Impacts of perceived risks on tourists' revisit intentions. Anatolia $A n$ International Journal of Tourism and Hospitality Research, 24(2), 173-187. https://doi.org/10.1080/13032917.2012.743921

Çetinsöz, B. C., \& Ege, Z. (2012). Turistlerin Demografik Özelliklerine Göre Risk Azaltma Stratejileri: Alanya Örneği. Anatolia: Turizm Araştırmaları Dergisi, 23(2), 159-172. https://doi.org/10.17123/atad.77865

Chen, C. F., \& Tsai, D. (2007). How destination image and evaluative factors affect behavioral intentions?. Tourism management, 28(4), 11151122 . 
Chen, X., Cheng, Z. F., \& Kim, G. B. (2020). Make it memorable: Tourism experience, fun, recommendation and revisit intentions of Chinese outbound tourists. Sustainability (Switzerland), 12(5), 1-24. https://doi.org/10.3390/su12051904

Chew, E. Y. T., \& Jahari, S. A. (2014). Destination image as a mediator between perceived risks and revisit intention: A case of post-disaster Japan. Tourism Management, 40, 382-393. https://doi.org/10.1016/j.tourman.2013.07.008

Chien, P. M., Sharifpour, M., Ritchie, B. W., \& Watson, B. (2017). Travelers' health risk perceptions and protective behavior: A psychological approach. Journal of Travel Research, 56(6), 744-759.

Choo, H. K., Choo, Y. (Clara), \& Kang, H. M. (2016). Do sport tourists' perceived risks affect their involvement and intention to (re)visit? An empirical study for risk-reduction strategies. International Journal of Sports Marketing and Sponsorship, 17(1), 19-36. https://doi.org/10.1108/IJSMS-02-2016-002

Clayton, A., Mustelier, L., \& Korstanje, M. E. (2014). Understanding Perceptions and Attitudes to Risk in the Tourism Industry. International Journal of Religious Tourism and Pilgrimage, 2(1), 2014. Retrieved https://arrow.dit.ie/ijrtp/vol2/iss 1/8

Cohen, S. A., Prayag, G., \& Moital, M. (2014). Consumer behaviour in tourism: Concepts, influences and opportunities. Current Issues in Tourism, 17(10), 872-909.

https://doi.org/10.1080/13683500.2013.850064

Cong, L. C. (2021). Perceived risk and destination knowledge in the satisfaction-loyalty intention relationship: An empirical study of european tourists in vietnam. Journal of Outdoor Recreation and Tourism, 33(October 2020), 100343. https://doi.org/10.1016/j.jort.2020.100343

Cui, F., Liu, Y., Chang, Y., Duan, J., \& Li, J. (2016). An overview of tourism risk perception. Natural Hazards, 82(1), 643-658. https://doi.org/10.1007/s11069-016-2208-1

Dedeoglu, B. B., Bilgihan, A., Ye, B. H., Buonincontri, P., \& Okumus, F. (2018). The impact of servicescape on hedonic value and behavioral intentions: The importance of previous experience. International Journal of Hospitality Management, 72(April 2017),

https://doi.org/10.1016/j.ijhm.2017.12.007

Dedeoğlu, B. B., \& Boğan, E. (2021). The motivations of visiting upscale restaurants during the Covid-19 pandemic: The role of risk perception and trust in government. International Journal of Hospitality Management, 95(February). https://doi.org/10.1016/j.ijhm.2021.102905
Deng, R., \& Ritchie, B. W. (2018). International university students' travel risk perceptions: An exploratory study. Current Issues in Tourism, 21(4).

https://doi.org/10.1080/13683500.2016.1142939

Eid, R. (2015). Integrating Muslim Customer Perceived Value, Satisfaction, Loyalty and Retention in the Tourism Industry: An empirical study. International Journal of Tourism Research, 17(3), 249-260. https://doi.org/10.1002/jtr.1982

Emami, A., \& Ranjbarian, B. (2019). The Perceived Risk of Iran as a Tourism Destination (A Mixed Method Approach). Iranian Journal of Management Studies, 12(1), 45-67. https://doi.org/10.22059/ijms.2018.245946.672909

Floyd, M. F., \& Pennington-Gray, L. (2004). Profiling risk perceptions of tourists. Annals of Tourism Research, 31(4), 1051-1054. https://doi.org/10.1016/j.annals.2004.03.011

Fuchs, G., \& Reichel, A. (2006). Tourist destination risk perception: The case of Israel. Journal of Hospitality and Leisure Marketing, 14(2), 83108. https://doi.org/10.1300/J150v14n02_06

Fourie, J., Rosselló-Nadal, J., \& Santana-Gallego, M. (2020). Fatal attraction: How security threats hurt tourism. Journal of Travel Research, 59(2), 209-219.

Soleimani, G. A., \& Einolahzadeh, H. (2018). The influence of service quality on revisit intention: The mediating role of WOM and satisfaction (Case study: Guilan travel agencies). Cogent Social Sciences, 4(1), 1-14. https://doi.org/10.1080/23311886.2018.1560651

Gong, X., \& Liang, M. (2019). Study on Risk Perception of Domestic Cruise Tourists. IOP Conference Series: Earth and Environmental Science, 252(4), $1-7$. $1315 / 252 / 4 / 042032$

González-Reverté, F., Díaz-Luque, P., Gomis-López, J. M., \& Morales-Pérez, S. (2018). Tourists' risk perception and the use of mobile devices in beach tourism destinations. Sustainability (Switzerland), 10(2). https://doi.org/10.3390/su10020413

Guliling, H. H., \& Aziz, Y. A. (2018). Historical Service Quality Assessment of Malaysia's World Heritage Site. Journal of International Business, Economics and Entrepreneurship, 3(2), 12-22. Retrieved from https://jibe.uitm.edu.my/images/dec2018/Hasnaw atifull.pdf

Gujarati, D. (2004). Basic Economecrics. Fourth Edition. The McGraw-Hil: New York.

Güvenek, B., \& Alptekin, V. (2015). Turistlere Yönelik Terör Saldırılarının Turizme Etkisi: Türkiye 
Üzerine Ampirik Bir Çalışma. Selçuk Üniversitesi / Sosyal Bilimler Meslek Yüksekokulu Dergisi, 17(1), 21-38.

Hasan, M. K., Ismail, A. R., \& Islam, M. F. (2017). Tourist risk perceptions and revisit intention: A critical review of literature. Cogent Business and Management, $4(1)$ https://doi.org/10.1080/23311975.2017.1412874

Hashim, N. A. A. N., Noor, M. A. M., Awang, Z., Che Aziz, R., \& Yusoff, A. M. (2018). The Influence of Tourist The Influence of Tourist Perceived Risk towards Travel Intention: A Conceptual Paper. International Journal of Academic Research in Business \& Social Sciences, 8(16), 92-102. https://doi.org/10.6007/IJARBSS/v8-i16/5120

Hosany, S., Prayag, G., Deesilatham, S., Cauševic, S., \& Odeh, K. (2015). Measuring Tourists' Emotional Experiences. Journal of Travel Research, 54(4), 482-495.

https://doi.org/10.1177/0047287514522878

Huang, X., Dai, S., \& Xu, H. (2020). Predicting tourists' health risk preventative behaviour and travelling satisfaction in Tibet: Combining the theory of planned behaviour and health belief model. Tourism Management Perspectives, 33 https://doi.org/10.1016/j.tmp.2019.100589

Huo, Y., \& Miller, D. (2007). Satisfaction Measurement of Small Tourism Sector (Museum): Samoa. Asia Pacific Journal of Tourism Research, 12(2), 103117. https://doi.org/10.1080/10941660701243331

Jacoby, J., \& Kaplan, L. B. (1972). The components of perceived risk. ACR special volumes.

Jin, N., Line, N. D., \& Merkebu, J. (2016). The Impact of Brand Prestige on Trust, Perceived Risk, Satisfaction, and Loyalty in Upscale Restaurants. Journal of Hospitality Marketing and Management, 25(5), 523-546. https://doi.org/10.1080/19368623.2015.1063469

Karamustafa, K., Fuchs, G., \& Reichel, A. (2013). Risk Perceptions of a Mixed-Image Destination: The Case of Turkey's First-Time Versus Repeat Leisure Visitors. Journal of Hospitality Marketing and Management, 22(3), 243-268. https://doi.org/10.1080/19368623.2011.641709

Karl, M., Muskat, B., \& Ritchie, B. W. (2020). Which travel risks are more salient for destination choice? An examination of the tourist's decisionmaking process. Journal of Destination Marketing \& Management, 18(January), 100487. https://doi.org/10.1016/j.jdmm.2020.100487

Khan, M. J., Khan, F., Amin, S., \& Chelliah, S. (2020). Perceived risks, travel constraints, and destination perception: A study on sub-saharan African medical travellers. Sustainability, 12(7), 2807.
Kim, L. H., Kim, D. J., \& Leong, J. K. (2005). The effect of perceived risk on purchase intention in purchasing airline tickets online. Journal of Hospitality and Leisure Marketing, 13(2), 33-53. https://doi.org/10.1300/J150v13n02_04

Kırlar, B., \& Ozgen, I. (2020). Turistlerin Terör Riski Algısı ve Riskle Başa Çıkma Davranışları. Anatolia: Tourism Research Journal, 31(2), 125137. https://doi.org/10.17123/atad.777512

Koc, E., \& Villi, B. (2021). Transformation of tourism and hospitality customers' perception of risk and customers' needs for control. Journal of Multidisciplinary Academic Tourism, 6(2), 117125. https://doi.org/10.31822/jomat.2021-6-2-117

Koçoğlu, C. M. (2016). Risk algısının yeniden satın alma davranışı üzerindeki etkisi: Havayolu sektöründe bir araştırma. Akademik Bakış Dergisi, Eylül$\operatorname{Ekim}(57), 246-263$.

Korstanje, M. (2009). Re-visitng risk perception theory in the context of travel. E-Review of Tourism Research, 7(4), 68-81. Retrieved from http://ertr.tamu.edu

Kovačić, S., Jovanović, T., Miljković, D., Lukić, T., Marković, S. B., Vasiljević, D. A., ... Ivkov, M. (2019). Are Serbian tourists worried? The effect of psychological factors on tourists' behavior based on the perceived risk. Open Geosciences, 11(1), 273-287. https://doi.org/10.1515/geo-2019-0022

Kozak, M., Crotts, J. C., \& Law, R. (2007). The impact of the perception of risk on international travellers. International Journal of Tourism Research, $9(4)$, 233-242. https://doi.org/10.1002/jtr.607

Larsen, S., Doran, R., \& Wolff, K. (2017). How psychology can stimulate tourist experience studies. Visitor experience design, 5, 13-29.

Li, Z., Sha, Y., Song, X., Yang, K., ZHao, K., Jiang, Z., \& Zhang, Q. (2020). Impact of risk perception on customer purchase behavior: a meta-analysis. Journal of Business \& Industrial Marketing; 35(1), 76-96. https://doi.org/10.1108/JBIM-122018-0381

Lu, H. Y. (2021). An Investigation of Factors Influencing the Risk Perception and Revisit Willingness of Seniors. Asia Pacific Management Review, (xxxx). https://doi.org/10.1016/j.apmrv.2021.01.002

Lv, X., Li, C., \& McCabe, S. (2020). Expanding theory of tourists' destination loyalty: The role of sensory impressions. Tourism Management, 77. https://doi.org/10.1016/j.tourman.2019.104026

Mansfeld, Y., Jonas, A., \& Cahaner, L. (2016). Between Tourists' Faith and Perceptions of Travel Risk. Journal of Travel Research, 55(3), 395-413. https://doi.org/10.1177/0047287514550099

Maria Gstaettner, A., Rodger, K., \& Lee, D. (2017). Visitor perspectives of risk management in a 
natural tourism setting: An application of the Theory of Planned Behaviour. Journal of Outdoor Recreation and Tourism, 19(October 2016), 1-10. https://doi.org/10.1016/j.jort.2017.04.001

Matiza, T. (2020). Post-Covid-19 crisis travel behaviour: towards mitigating the effects of perceived risk. Journal of Tourism Futures, 2012(April). https://doi.org/10.1108/JTF-04-2020-0063

Mawby, R. I., Ozascilar, M., \& Ziyalar, N. (2021). Risk, safety and security among visitors to Istanbul. Tourism and Hospitality Research, 21(1), 61-72. https://doi.org/10.1177/1467358420948918

Nazir, M. U., Yasin, I., \& Tat, H. H. (2021). Destination image's mediating role between perceived risks, perceived constraints, and behavioral intention. Heliyon.

https://doi.org/10.1016/j.heliyon.2021.e07613

Nguyen Viet, B., Dang, H. P., \& Nguyen, H. H. (2020). Revisit intention and satisfaction: The role of destination image, perceived risk, and cultural contact. Cogent Business and Management, $7(1)$. https://doi.org/10.1080/23311975.2020.1796249

Oliver, R. L. (1999). Whence Consumer Loyalty? Journal of $\quad$ Marketing, 63(1999), 33. https://doi.org/10.2307/1252099

Osland, G. E., Mackoy, R., \& McCormick, M. (2017). Perceptions of personal risk in tourists' destination choices: nature tours in Mexico. European Journal of Tourism, Hospitality and Recreation, $\quad$ 8(1), 38-50. https://doi.org/10.1515/ejthr-2017-0002

Ozascilar, M., Mawby, R. I., \& Ziyalar, N. (2019). Perceptions of risk on vacation among visitors to Istanbul. Safer Communities, 18(1), 16-29. https://doi.org/10.1108/SC-06-2018-0017

Park, S., \& Tussyadiah, I. P. (2017). Multidimensional Facets of Perceived Risk in Mobile Travel Booking. Journal of Travel Research, 56(7), 854867. https://doi.org/10.1177/0047287516675062

Pelaez, A., Chen, C. W., \& Chen, Y. X. (2019). Effects of Perceived Risk on Intention to Purchase: A MetaAnalysis. Journal of Computer Information Systems, $\quad 59(1), \quad 73-84$. https://doi.org/10.1080/08874417.2017.1300514

Perić, G., Dramićanin, S., \& Conić, M. (2021). The impact of serbian tourists' risk perception on their travel intentions during the Covid-19 pandemic. European Journal of Tourism Research, 27(1), 122.

Quintal, V. A., Lee, J. A., \& Soutar, G. N. (2010). Risk, uncertainty and the theory of planned behavior: A tourism example. Tourism Management, 31(6), 797-805.

https://doi.org/10.1016/j.tourman.2009.08.006
Rahmafitria, F., Suryadi, K., Oktadiana, H., Putro, H. P. H., \& Rosyidie, A. (2021). Applying knowledge, social concern and perceived risk in planned behavior theory for tourism in the Covid-19 pandemic. Tourism Review, 76(4), 809-828. https://doi.org/10.1108/TR-11-2020-0542

Rahman, M. K., Gazi, M. A. I., Bhuiyan, M. A., \& Rahaman, M. A. (2021). Effect of Covid-19 pandemic on tourist travel risk and management perceptions. Plos One, 16(9), e0256486. https://doi.org/10.1371/journal.pone.0256486

Reisinger, Y., \& Mavondo, F. (2005). Travel anxiety and intentions to travel internationally: Implications of travel risk perception. Journal of Travel Research, 43(3), 212-225. https://doi.org/10.1177/0047287504272017

Reisinger, Y., \& Mavondo, F. T. (2006). Cultural differences in travel risk perception. Journal of Travel and Tourism Marketing, 20(1), 13-31. https://doi.org/10.1300/J073v20n01_02

Ritchie, B. W., \& Jiang, Y. (2019). A review of research on tourism risk, crisis and disaster management: Launching the annals of tourism research curated collection on tourism risk, crisis and disaster management. Annals of Tourism Research, 79. https://doi.org/10.1016/j.annals.2019.102812

Ruan, W. Q., Li, Y. Q., \& Liu, C. H. S. (2017). Measuring tourism risk impacts on destination image. Sustainability (Switzerland), $9(9), \quad 1-15$. https://doi.org/10.3390/su9091501

Savasc1, U. (2020). Destinasyon Imaji ve Algllanan riskin, Davranıssal Niyete Etkisi: Bodrum Örnĕ̆i. Canakkale Onsekiz Mart Üniversitesi, Lisansüstü Eğitim Enstitüsü, Seyahat İşletmeciliği ve Turizm Rehberliği Anabilimdalı, Yüksek Lisans Tezi.

Savaşçı, U., \& Yıldırım, H. M. (2021). Destinasyon İmajı ve Algılanan Riskin, Davranışsal Niyete Etkisi: Bodrum Örneği. GSI Journals Serie A: Advancements in Tourism Recreation and Sports Sciences, 4(2), 17-36. https://doi.org/10.53353/atrss.887811

Seçilmiş, C., Özdemir, C., \& Kılıç, İ. (2021). How travel influencers affect visit intention? The roles of cognitive response, trust, Covid-19 fear and confidence in vaccine. Current Issues in Tourism, $1-16$. https://doi.org/10.1080/13683500.2021.1994528

Şen Küpeli, T., \& Özer, L. (2020). Assessing perceived risk and perceived value in the hotel industry: an integrated approach. Anatolia An International Journal of Tourism and Hospitality Research, 31(1), $111-130$ https://doi.org/10.1080/13032917.2020.1711785

Sert, A. N. (2019). The Impact of Tourist Safety on Risk Reduction Behavior, Recommendation and 
Revisit Intention: A Case Study on Iranian Tourists in Istanbul. Anemon Journal of Social Sciences of Mus Alp. University, 7(5), 71-82.

Sharifpour, M., Walters, G., Ritchie, B. W., \& Winter, C. (2014). Investigating the Role of Prior Knowledge in Tourist Decision Making: A Structural Equation Model of Risk Perceptions and Information Search. Journal of Travel Research, 53(3), 307-322. Link

Simpson, P. M., \& Siguaw, J. A. (2008). Perceived travel risks: The traveller perspective and manageability. International Journal of Tourism Research, 10(4), 315-327.

Sofiichuk, K. (2018). Risks of the Tourism Industry in Ukraine. Journal of Environmental Management and Tourism. Link

Sohn, H. K., Lee, T. J., \& Yoon, Y. S. (2016). Relationship between Perceived Risk, Evaluation, Satisfaction, and Behavioral Intention: A Case of LocalFestival Visitors. Journal of Travel and Tourism Marketing, 33(1), 28-45. Link

Sönmez, S. F., \& Graefe, A. R. (1998). Influence of terrorism risk on foreign tourism decisions. Annals of Tourism Research, 25(1), 112-144. https://doi.org/10.1016/s0160-7383(97)00072-8

Supani, I. D., \& Abd Hamid, Z. (2020). Risk perception towards international travellers' destination choice: A case of Sabah. Journal of Tourism, Hospitality \& Culinary Arts, 12(1), 1-13.

Tavitiyaman, P., \& Qu, H. (2013). Destination Image and Behavior Intention of Travelers to Thailand: The Moderating Effect of Perceived Risk. Journal of Travel and Tourism Marketing, 30(3), 169-185. $\underline{\text { Link }}$

Teeroovengadum, V., Seetanah, B., Bindah, E., Pooloo, A., \& Veerasawmy, I. (2021). Minimising perceived travel risk in the aftermath of the Covid-19 pandemic to boost travel and tourism. Tourism Review, 76(4), 910-928. Link

Tiwari, A. K., Das, D., \& Dutta, A. (2019). Geopolitical risk, economic policy uncertainty and tourist arrivals: Evidence from a developing country. Tourism Management, 75(May), 323-327. Link

Tosun, C., Dedeoğlu, B. B., \& Fyall, A. (2015). Destination service quality, affective image and revisit intention: The moderating role of past experience. Journal of Destination Marketing and Management, 4(4), 222-234. Link

Tse, D. K., \& Wilton, P. C. (1988). Models of Consumer Satisfaction Formation: An Extension. Journal of Marketing Research, 25(2), 204. Link

Turkmendag, T., \& Uygur, S. (2020). An Investigation of the Effect of Perceived Risk on Repurchase Intention in Online Vacation Purchases. Tourism Academic Journal, $7(2), 255-266$.
Demirel, E., \& Ciftci, G. (2020). A systematic literature review of the theory of planned behavior in tourism, leisure and hospitality management research. Journal of Hospitality and Tourism Management, 43(April), 209-219. Link

Ünal, A. (2020). Yerli Turistlerin Algıladıkları Seyahat Risklerinin Destinasyo n Satın Alma Süreçlerine Etkilerinin Belirlenmesine Yönelik Bir Araştırma. I $\breve{g} d ı r$ Üniversitesi Sosyal Bilimler Dergis, (24), 403-424.

Vada, S., Prentice, C., Scott, N., \& Hsiao, A. (2020). Positive psychology and tourist well-being: A systematic literature review. Tourism Management Perspectives, 33, 100631. Link

Wen, J., Kozak, M., Yang, S., \& Liu, F. (2021). Covid-19: potential effects on Chinese citizens' lifestyle and travel. Tourism Review, 76(1), 74-87. Link

Wolff, K., Larsen, S., \& Øgaard, T. (2019). How to define and measure risk perceptions. Annals of Tourism Research, 79. Link

Xie, C., Zhang, J., \& Morrison, A. M. (2021). Developing a Scale to Measure Tourist Perceived Safety. Journal of Travel Research, 60(6), 1232-1251. $\underline{\text { Link }}$

Yamane, T. (2006). Elementary Sampling Theory. New Jersey, United States: Prentice Hall.

Yang, C. L., \& Nair, V. (2014). Risk Perception Study in Tourism: Are we Really Measuring Perceived Risk? Procedia - Social and Behavioral Sciences, 144(2006), 322-327. Link

Yazid, A. S., Yusof, M. Y. M., Rashid, N., Ghazali, P. L., Salleh, F., Mahmod, M. S., \& Mahmood, S. (2018). A Mediating Effect of Risk Perception on Factors Influencing Tourist Intention to Travel: A Conceptual Framework. International Journal of Academic Research in Business and Social Sciences, 8(11), 1246-1255. Link

Zhan, L., Zeng, X., Morrison, A. M., Liang, H., \& CocaStefaniak, J. A. (2020). A risk perception scale for travel to a crisis epicentre: visiting Wuhan after Covid-19. Current Issues in Tourism. Link 
2022, 7 (1): 81-96

https://doi.org/10.31822/jomat.2022-7-1-81

\title{
INFO PAGE \\ Determining destination risk perceptions, their effects on satisfaction, revisit and recommendation intentions: Evidence from Sanliurfa/Turkey
}

\begin{abstract}
Visitors' risk perception plays a vital role in their destination choice, intention to return, satisfaction and recommendations to others. At the same time, perceived risks affect destination image, which in turn causes increased or decreased demand for attractions of destinations. The aim of this study is to determine risk dimensions and their effects on recommendation and revisit intentions. Scale is most widely used in tourism research. This scale consists of six dimensions, namely, physical, time, social, performance, financial, and psychological risks, which consist of 28 items. A total of 471 respondents were collected via convenience sampling method among domestic tourists who visited Sanliurfa from May to June 2021. The results of the study indicated a weak inverse and significant relationship between the performance, social, physical, psychological, financial, and time risk perception of the participants and general satisfaction levels. Meanwhile, there is a moderately strong, inverse and significant relationship between all dimensions of risk perception among the participants and their recommendation and revisit intention. Thus, perceptions of risk dimensions have a strong negative influence on overall satisfaction, recommendation, and revisit intentions. By employing three regression models, the present study reported that time and psychological risks highly affect all dependent variables. Furthermore, overall satisfaction is significantly affected by the physical and performance dimensions. Recommendation intention is affected by the financial dimension beyond the aforementioned dimensions. The overall satisfaction levels of the participants were highly correlated with their recommendation levels and revisit intention. At the same time, their recommendation intention was highly correlated with their level of revisit intention. It might be said that visitors may change their future behaviors according to travel risk perceptions. Finally, the study revealed that understanding of customers risk perception is essential to all tourism and hospitality stakeholders.
\end{abstract}

Keywords: Destination, recommendation intention, revisit intention, risk perception, satisfaction, Sanliurfa, tourists

\section{Authors}

Author statement: Author(s) declare(s) that All procedures performed in studies involving human participants were in accordance with the ethical standards of the institutional and/or national research committee and with the 1964 Helsinki declaration and its later amendments or comparable ethical standards. Declaration of Conflicting Interests: The author(s) declared no potential conflicts of interest with respect to the research, authorship, and/or publication of this article

Ethics Committee Satatement: Ethics committee report is available for this research and it has been documented to the journal.

Ethics committee: Harran University Rectorate

Social and Human Sciences Ethics Committee

Date of ethics committee decision: 20.05.2021

Ethics committee decision number: 31966 